Hambly, J. S. (1958). J. gen. Microbiol. 18, 285-293

\title{
The Precipitating Antigen of Streptococcus pyogenes Type 4
}

\author{
BY JEAN S. HAMBLY \\ Streptococcal Reference Laboratory, Public Health Laboratory Service, \\ Colindale, London, N.W. 9
}

SUMMARY: The antigen found in acid extracts of some type-4 Group-A streptococci which is responsible for precipitation with specific antisera is resistant to digestion with trypsin and pepsin when in the cell. It becomes sensitive to these enzymes after extraction with boiling $\mathrm{HCl}$. It is not an $\mathrm{M}$ antigen but resembles a $\mathrm{T}$ antigen although it is more heat-stable at low $\mathrm{pH}$ values than the $\mathbf{T}$ antigen of most other types.

Another precipitating antigen, common in freshly isolated type-4 strains but not restricted to them, is described and referred to as ' $B$ '. Its role as a blocking agent in inhibiting the formation of $\mathrm{M}$ antibody is discussed.

The $\mathbf{M}$ antigen is now accepted as the basis for differentiating the serotypes of Streptococcus pyogenes (Lancefield's Group A). This antigen, which is a protein sensitive to digestion by trypsin and pepsin, has two important characters: (1) when extracted with hot acid by the Lancefield method (Swift, Wilson \& Lancefield, 1943) it precipitates specifically with absorbed antisera prepared against strains of the same $M$ type; (2) antibodies to $M$ antigen will specifically protect mice against infection with streptococci of the same type (Lancefield \& Perlmann, 1952a). The addition to fresh human blood of rabbit serum containing an $\mathbf{M}$ antibody also enhances the bactericidal property of the blood for strains possessing that particular $M$ antigen (Maxted, 1956).

It is difficult to prepare satisfactory anti-M serum for streptococci of type 4 ; the precipitate obtained even with extracts of the vaccine strain is usually weak as compared with the homologous precipitate of other types. Moreover, Maxted (1956) found that a type-4 antiserum which gave this weak precipitation did not enhance the bactericidal property of human blood against type-4 organisms. There is no evidence about mouse protection, since none of the strains so far tested have been sufficiently virulent to be tested in mice.

In certain batches of anti-M sera cross-reactions have been noted in precipitin tests between types 4, 26, 29 and 46. The reaction was of the strength of a usual type-4 precipitation and did not approach that given by normal type 26 , 29 or $46 \mathrm{M}$-antigen extracts with their homologous antisera. Since types 4,26 , 29 and 46, together with type 24, possess a common $\mathbf{T}$ antigen (Stewart, Lancefield, Wilson \& Swift, 1944) it seemed possible that the cross-reaction might be due to a $\mathrm{T}$ antigen which survived extraction by hot acid, even though the $\mathbf{T}$ antigen of most types is destroyed by this treatment. If this were so, the rather poor precipitin reaction obtained between type-4 Lancefield extracts and type 4 antiserum might be due, not to an $M$ antigen, but to a $T$ antigen. This appears to be the case. 


\section{METHODS}

Organisms used. The following strains of Streptococcus pyogenes were used:

\begin{tabular}{|c|c|}
\hline Type & Strains \\
\hline 4 & $\begin{array}{l}\text { T4/95/Rb5/7 } \\
\text { (also known } \\
\text { as } 4990 \text { ) }\end{array}$ \\
\hline 4 & $\left.\begin{array}{l}\text { R54.2692 } \\
\text { R54.2707 } \\
\text { R54.2604 } \\
\text { R55.17 }\end{array}\right\}$ \\
\hline 1 & SF $130 / 13$ \\
\hline 6 & S 43 glossy \\
\hline 6 & $\mathrm{~S} 43 / 78$ \\
\hline $\begin{array}{c}11 \\
\text { ovisional } \\
\text { pe B3264 }\end{array}$ & $\begin{array}{l}\text { T } 11 / 54 / 4 \\
\text { C } 632\end{array}$ \\
\hline
\end{tabular}

Source of strain

Original Griffith Type-4 strain passed through 95 mice and 5 rabbits by Lancefield Strains freshly isolated from throats of scarlet fever
patients

Original Griffith Type 1 passed through 13 mice by Lancefield

Isolated by Dochez, Avery \& Lancefield

Isolated by Dochez, Avery \& Lancefield, passed through 75 mice by Lancefield; through 3 mice at Colindale

NE73 $T$ passed through 58 mice by Lancefield Lancefield (originally from Griffith)

Cultivation of type-4 strains. Type-4 strains were grown in a modified ToddHewitt broth for $18 \mathrm{hr}$. at $37^{\circ}$. This temperature was found to favour production of the antigen responsible for both agglutination and precipitation.

\section{Recognition of antigens}

Slide agglutination. Overnight cultures in $5 \mathrm{ml}$. broth were centrifuged and all but $0.5 \mathrm{ml}$. of the supernatant fluid removed. Pancreatic extract (Cole \& Onslow) was added, the $\mathrm{pH}$ value adjusted to 8 , and the suspensions of organisms then incubated at $37^{\circ}$ for $2 \mathrm{hr}$. This treatment renders the suspensions smooth and usable for agglutination and also destroys the $\mathbf{M}$ antigen when present.

Lancefield extracts for $M$ antigen. The cocci from $50 \mathrm{ml}$. of overnight broth cultures were suspended in $0.4 \mathrm{ml}$. of $0.2 \mathrm{~N}-\mathrm{HCl}$ and placed in a boiling waterbath for 10 min. After cooling the mixture was neutralized and the supernatant fluid used as the extract. Precipitin tests were carried out in capillary tubes (Swift et al. 1943).

Pakula extracts for $T$ antigen (Pakula, 1951). Cocci from $100 \mathrm{ml}$. of an overnight broth culture were washed in saline, suspended in $2.7 \mathrm{ml}$. of buffer,

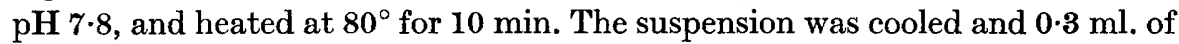
pancreatic extract was added, the $\mathrm{pH}$ value adjusted to 8 and the mixture held at $50^{\circ}$ in a water-bath for $2 \mathrm{hr}$. The suspension was then spun, the supernatant removed and adjusted to $\mathrm{pH} 2$ with $\mathrm{N}-\mathrm{HCl}$. The $\mathrm{T}$ antigen precipitated at this $\mathrm{pH}$ value when left overnight in the cold. It could then be removed from the centrifuged supernatant fluid and redissolved in $0 \cdot 1 \mathrm{ml}$. buffer at $\mathrm{pH} \mathbf{7 \cdot 8}$. The extracts were tested in capillary tubes in the same way as Lancefield extracts.

Treatment of antigens with trypsin and pepsin. Pancreatic extract was used as a source of trypsin, but all the more important results were confirmed by using a solution of crystalline trypsin (Armour and Co., Ltd.); a $0.0007 \%$ (w/v) solu- 
tion of crystalline trypsin was found to have an effect equivalent to the solution of pancreatic extract used. Crystalline pepsin (Armour and Co., Ltd.) was used in $10 \%(\mathrm{w} / \mathrm{v})$ solution.

When Lancefield extracts were treated with trypsin or pepsin, 0.04 ml. of the enzyme solution was added to $\mathbf{0 . 2} \mathrm{ml}$. of the extract; the $\mathrm{pH}$ value was adjusted to 8 for trypsin and $\mathbf{2 . 5}$ for pepsin. The extracts were held at $37^{\circ}$ for $2 \mathrm{hr}$., the $\mathrm{pH}$ value re-adjusted to neutral, and the extract tested for precipitation with appropriate antisera.

When enzyme treatment was carried out on the streptococcal cells, cocci from an overnight culture in $50 \mathrm{ml}$. broth were suspended in $0.7 \mathrm{ml}$. of appropriate buffer and $\mathbf{0 . 3} \mathrm{ml}$. of enzyme solution added. The suspensions were held at $37^{\circ}$ for $2 \mathrm{hr}$. The cocci were then separated from the buffer by centrifugation, extracted by the Lancefield method and tested in the usual way. In all experiments controls were included, using buffer solution without the addition of enzyme.

Preparation of antisera. Antisera were prepared by the inoculation of rabbits with whole cocci killed by heat at $56^{\circ}$ for anti-M or with cocci digested with trypsin, washed and killed with formalin for anti-T sera. In either case growth from an overnight broth culture was concentrated 10 times for use as vaccine. After a sensitizing dose of $0.5 \mathrm{ml}$. the rabbits were given $1 \mathrm{ml}$. doses on 3 consecutive days followed by 4 days rest. This dosage was repeated weekly, usually for 4-5 weeks.

The type-4 antiserum used in most of this work was prepared against strain 4990.

Absorption of antisera. For agglutination and precipitin tests the antisera were absorbed with cocci of type 6 , strain $S 43$ glossy, to remove group and nonspecific antibodies. Antisera made from freshly isolated type-4 strains had also to be absorbed with a type-11 strain, $\mathrm{T} 11 / 54$, to remove the $\mathrm{B}$ antibody, which is described more fully in the text. $\mathrm{B}$ antibody was not present in sera prepared against strain 4990 .

\section{Preparation of fractions of type-4 streptococci for absorption of sera}

$T$ fraction. The absorbing fraction was the precipitate brought down at $\mathrm{pH} 2$ in a Pakula extract. The cocci from $500 \mathrm{ml}$. broth incubated for $48 \mathrm{hr}$. yielded sufficient crude $\mathbf{T}$ antigen to absorb all the $T$ antibody from $0.3 \mathrm{ml}$. of type-4 antiserum.

' $M$ ' fraction. Cocci were extracted by the Lancefield method; $2 \cdot 5$ vol. of absolute ethanol were then added to the extract. This precipitated a fraction which on redissolving gave a precipitation reaction with type-4 antiserum but contained no group polysaccharide. The extract was reprecipitated three times with ethanol and the final precipitate was used for absorption of serum. Cocci grown in $500 \mathrm{ml}$. broth for $48 \mathrm{hr}$. yielded an absorbing dose for $\mathbf{0 . 3} \mathrm{ml}$. of serum.

Strain 4990 was used in the preparation of both fractions. Absorptions were carried out by mixing the antiserum with the antigen fraction, incubating for $2 \mathrm{hr}$. at $37^{\circ}$ and then placing the mixture in the cold overnight before testing. In all cases controls were included. 


\section{RESULTS}

The effect of trypsin and pepsin on the type-4 precipitating antigen

The effect of trypsin and pepsin was tested on Lancefield extracts and live streptococci of types 4 and 1 . Whereas trypsin digestion destroyed the serological activity of the type-4 antigen extracted by hot hydrochloric acid, it failed to destroy that of the antigen extracted at $50^{\circ}$ or that from whole cocci treated with trypsin before extraction (Table 1). The type-1 antigen was destroyed by trypsin both in the extract and the cocci.

Table 1. The effect of trypsin and pepsin on the type-4 precipitating antigen

Treatment of cocci or extracts

\begin{tabular}{|c|c|c|c|c|}
\hline None & $\begin{array}{c}\text { Trypsin } \\
\text { digestion } \\
\text { at } \mathrm{pH} 7 \cdot 8\end{array}$ & $\begin{array}{c}\text { Buffer at } \\
\text { pH } \mathbf{7 \cdot 8}\end{array}$ & $\begin{array}{c}\text { Pepsin } \\
\text { digestion } \\
\text { at } \mathrm{pH} \mathrm{2.5}\end{array}$ & $\begin{array}{c}\text { Buffer at } \\
\text { pH 2.5 }\end{array}$ \\
\hline
\end{tabular}

Acid extracts made from untreated cocei

$\begin{array}{llllll}\text { Untreated cocci } & & & \\ \text { Type } 4 \text { extracted at } 100^{\circ} & ++1++ & -1- & +1+ & -1- & +1+ \\ \text { Type 4 extracted at } 50^{\circ} & +1+ & \operatorname{tr} /+ & +1+ & \text { N.D. } & \text { N.D. } \\ \text { Type } 1 \text { extracted at } 100^{\circ} & ++1++ & -1- & +1+ & -1- & ++1++ \\ \text { Cocci treated before acid } & & & & & \\ \text { extraction } & ++1++ & +1++ & ++1++ & -1- & ++1++ \\ \text { Type 4 } & ++1++ & -1- & ++1++ & -1- & ++1++ \\ \text { Type 1 } & & \end{array}$

$-=$ no precipitation; $+=$ moderate and ++ strong precipitation. Readings taken after $2 \mathrm{hr}$. at $37^{\circ}$ and $18 \mathrm{hr}$. at $4^{\circ}$. N.D. $=$ not done. $++/++=2 \mathrm{hr}$. reading/18 hr. reading.

Pepsin had an interesting effect in that it appeared, from the preliminary results, to digest the antigen, both in the extract and on the living organism. This suggested that the type-4 precipitating antigen was similar in character to the $\mathbf{R}$ antigen of type 28 which is digested by pepsin but not by trypsin (Lancefield \& Perlmann, 1952b). It was found however, that the type-4 antigen, unlike the $\mathbf{R}$ antigen of type 28 , could be detected in considerable quantity in the supernatant fluid from a pepsin digest even after $18 \mathrm{hr}$. incubation at $37^{\circ}$. The action of pepsin on type-4 organisms seemed, therefore, to be simply the complete and rapid release of the antigen into solution.

Type-4 cocci were also rendered completely inagglutinable by anti- $T$ sera after treatment with pepsin for $2 \mathrm{hr}$. at $37^{\circ}$, thus confirming that the responsible antigen had been removed from the cell surface. Pepsin did not have this effect on the other types tested, namely 1,2 and 3 . The antigen responsible for precipitation in acid extracts of type 4 is thus resistant to digestion with trypsin and pepsin while attached to the cells, although it may become sensitive to digestion by these enzymes after extraction by boiling at low $\mathrm{pH}$; it cannot therefore be typical $\mathbf{M}$ antigen.

\section{Absorption experiments}

Absorption of sera with the crude $\mathbf{T}$ fraction completely removed the antibody responsible for precipitation with both Lancefield and Pakula extracts 

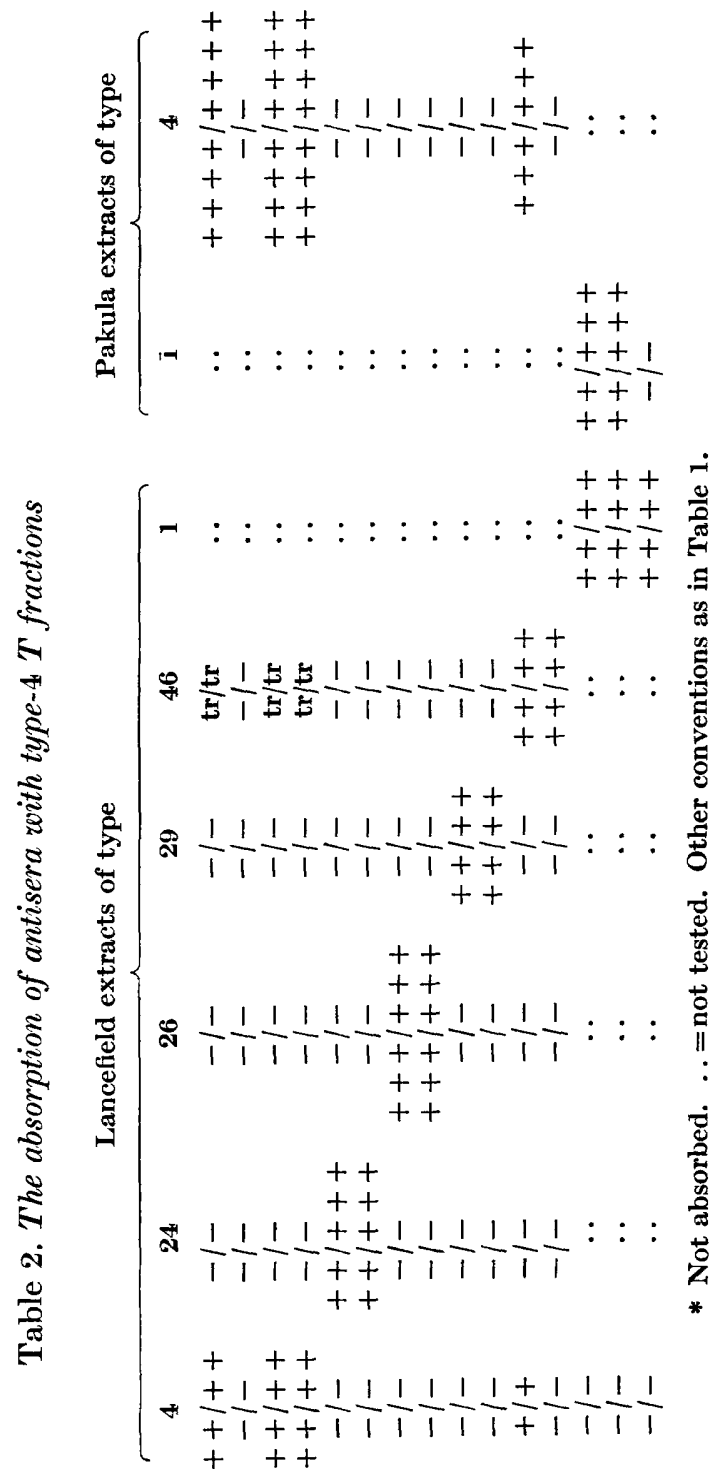

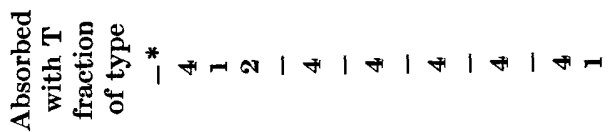

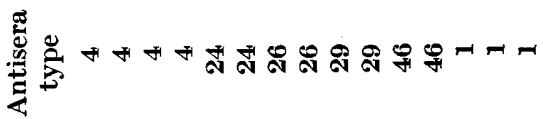


and for agglutination of type-4 cocci (Table 2). Similar doses of type-4 T fraction did not remove the specific precipitating antibody ( $M$ antibody) from sera of types $24,26,29$ and 46 or 1 . Nor did a similar dose of $T$ fraction from a type- 1 strain remove the precipitating $M$ antibody from a type 1 anti-M serum, although it removed the $\mathbf{T}$ antibody also present in that serum.

The fraction prepared from the Lancefield extract of type 4, when used for absorption, not only decreased the ability of the serum to precipitate with type-4 Lancefield extracts but also decreased its agglutination titre from $1 / 640$ to $1 / 40$ (Table 3; agglutination was used to estimate antibody in this experi-

Table 3. The absorption of antisera with type-4 ' $M$ ' fraction

\begin{tabular}{|c|c|c|c|c|c|}
\hline \multirow{2}{*}{$\begin{array}{c}\text { Antisera } \\
\text { type }\end{array}$} & \multirow{2}{*}{$\begin{array}{l}\text { Absorbed with } \\
\text { ' } M \text { ' fraction } \\
\text { of type }\end{array}$} & \multicolumn{2}{|c|}{$\begin{array}{l}\text { Precipitin reaction of Lancefield } \\
\text { extracts of type }\end{array}$} & \multicolumn{2}{|c|}{$\begin{array}{c}\text { Agglutination titre using } \\
\text { trypsin-treated cocci of } \\
\text { type }\end{array}$} \\
\hline & & 4 & 6 & 4 & 6 \\
\hline 4 & $-*$ & $++1+t$ & $-1-$ & $1 / 640$ & N.D. \\
\hline 4 & 4 & $-1-$ & $-1-$ & $1 / 40$ & N.D. \\
\hline 4 & 6 & $++1++$ & $-1-$ & $1 / 640$ & N.D. \\
\hline 6 & $-*$ & $-1-$ & $++1++$ & .. & $1 / 1280$ \\
\hline 6 & 4 & $-1-$ & $++1+t$ & .. & $1 / 1280$ \\
\hline 6 & 6 & $-1-$ & $-1-$ & . & $1 / 1280$ \\
\hline
\end{tabular}

Conventions as in Table 1.

ment for technical reasons). It was not possible, by increasing the absorbing dose, to remove the type-4 agglutinin completely. This may indicate that type 4 has two trypsin-resistant antigens, one of which is extracted by hot acid while the other, like a true $\mathbf{T}$ antigen, is destroyed.

\section{Preparation of type 4 anti-T serum}

An antiserum was prepared against type-4 streptococci which had been digested with trypsin. An antiserum made in this way to a satisfactory $M$ type, such as 3,5 or 12 , contains no demonstrable $M$ antibody; the type- 4 antiserum, however, gave as good precipitin reactions with Lancefield extracts as one prepared against organisms not treated with trypsin.

\section{Preparation of antiserum against freshly isolated strains of type 4}

Type-4 strains are isolated from cases of acute illness and one might expect that at some stage or under certain conditions they possess a true $\mathbf{M}$ antigen. An attempt was therefore made to produce anti-M sera by the use of freshly isolated strains. Four different vaccines were used for preparing these antisera.

(1) Prepared by the usual method for anti-M sera described under methods, using strains R54.2604 and R55.17.

(2) Prepared by a modification of the method described by Conroy \& Updyke (1954) using mechanically disrupted cocci of strains R54.2692 and R 54.2707. The cocci were washed, suspended in saline and shaken in a tissue disintegrator (Mickle), until they became Gram-negative and partially disinte- 
grated. The suspension was centrifuged at $4000 \mathrm{rev}$./min. for $30 \mathrm{~min}$., and the deposit was then resuspended in saline and heated at $56^{\circ}$.

(3) A heat-killed unwashed broth culture of strain R55.17.

(4) A culture of strain R54.2692 grown in human blood and killed with formalin.

The six antisera prepared by these methods were tested for precipitins and bactericidal antibodies. All the antisera prepared by these methods, with the exception of that made by method 4, contained precipitins, but in each case these could be shown to be directed to the $\mathbf{T}$ antigen. Although three out of four of the strains grew well in fresh heparinized human blood, which in itself suggested the presence of an $M$ antigen, none of the antisera prepared increased the bactericidal activity of blood.

\section{The ' $B$ ' antigen present in type-4 strains}

It was noticed that extracts of all the freshly isolated type-4 strains tested gave a precipitin reaction with a serum $(\mathbf{R} 432)$ prepared against the provisional type B 3264. The antigen responsible for this reaction, provisionally referred to as the ' $\mathrm{B}$ ' antigen, is, like the $\mathrm{M}$ antigen, best extracted with $0.2 \mathrm{~N}-\mathrm{HCl}$ at $100^{\circ}$ from cultures grown at $37^{\circ}$ in Todd-Hewitt broth. It can also be extracted by heating at $100^{\circ}$ for $10 \mathrm{~min}$. at alkaline or neutral $\mathrm{pH}$ values or by autoclaving at $10 \mathrm{lb}$./sq.in. for $10 \mathrm{~min}$. in $\mathrm{pH} 7 \cdot 8 \mathrm{buffer}$; but not with acid at $50^{\circ}$. The antigen is sensitive to digestion by trypsin or pepsin. It appears to be lost or changed when a strain is subjected to repeated passage through mice.

The main interest of the $\mathbf{B}$ antigen is that it is found almost exclusively among types for which satisfactory anti-M sera are difficult to prepare. Lancefield extracts of $\mathbf{3 3 2}$ freshly-isolated strains were tested for precipitation against an antiserum containing $B$ antibody. The 55 extracts that reacted with the anti-B serum were from strains with various agglutination patterns but the only strains whose extracts precipitated with other available sera were of types 2,4 and 28 . The type-4 and -28 sera were certainly not anti- $M$ and the type-2 serum, although it contained antibody to the $M$ antigen, also contained antibody to T. Maxted (1953) has shown that the type-2 $T$ antigen is not typical in its sensitivity to heat so that one cannot be certain whether this reaction was due to $\mathbf{M}$ or $\mathbf{T}$. The types that did not precipitate with $\mathrm{B}$ antibody were $\mathbf{1 , 3 , 5}$, $6,12,14,18,19,30$.

Among the collection of strains maintained in this laboratory the $\mathbf{B}$ antigen has been identified among representatives of types $2,4,8,9,11,13,22,25,27$, 28 , but not all the strains of a particular type possess it. Confusion can result when antisera are prepared against vaccine strains containing a $B$ antigen but are tested against strains lacking it. We have often noted that new antisera for the 'difficult' types appear fully absorbed when tested against the standard set of strains used for preparing $M$ antisera, but give numerous crossreactions when used for the routine typing of freshly-isolated strains; the strains of the standard set have mostly had numerous mouse passages.

The presence of the $\mathbf{B}$ antigen in a strain seems to make it less suitable as a vaccine strain for the production of $M$ antiserum. Even apart from the extra 
absorption involved, it has been noticed, particularly in the case of type $\mathbf{9}$, that stronger anti-M serum is produced against a strain that does not possess the $\mathbf{B}$ antigen than against others that do.

\section{DISCUSSION}

A close relationship exists between M-antigen production and the ability of the strain to resist phagocytosis (Wiley \& Wilson, 1956). If it be true that the $M$ antigen is needed for a strain to be virulent, one would expect that strains of type 4 isolated from cases of acute streptococcal disease would not differ in this respect from other types. Yet it has so far proved impossible to demonstrate unequivocally the production of an anti-M serum. This might be due simply to an unfortunate selection of vaccine strains, but there are two other possible explanations. The $M$ antigen, although present in the organism, may be masked by another antigen to which the antibody response is stronger. For example, with type 28 , antiserum containing the $R$ antibody is very easily produced; it was only after repeated mouse-passage of a strain that Lancefield was able to produce an antiserum which appears to have the properties of a true anti-M serum (Lancefield \& Perlmann, 1952b). In the case of type 4, either the type-4 $\mathrm{T}$ antigen or the $\mathrm{B}$ antigen might be responsible for masking.

Alternatively, the $M$ antigen may be readily lost from the type-4 organism on isolation and passage through laboratory media as happens with some strains (Wormald, 1956).

Against all this, however, there is the possibility that type-4 strains do not possess an $\mathrm{M}$ antigen similar to that of other types and that their virulence depends on some other factor. It is curious that several freshly isolated type-4 strains have been found to grow well in human blood-a capacity that characterizes M-containing strains-and yet these strains failed to stimulate the production of $\mathbf{M}$ antibodies in rabbits.

Whatever the explanation of these observations, it seems clear that the antigen responsible for the precipitation reaction with our currently available type-4 antisera is not due to an $M$ antigen. This finding, with the comparable observations on type-2 streptococci, emphasizes the necessity of making extensive verification tests before accepting such precipitation reactions as indicating the presence of $\mathbf{M}$ antigen.

\section{REFERENCES}

Conroy, E. \& UPDYKE, E. L. (1954). The use of a fraction of mechanically disrupted cells for production of group A streptococcus typing antisera. Science, 119, 69.

Lancefield, R. C. \& Perlmann, G. E. (1952 $a$ ). Preparation and properties of typespecific $M$ antigen isolated from a group $A$, type 1 hemolytic streptococcus. J. exp. Med. 96, 71 .

Lancefield, R. C. \& Perlmann, G. E. (1952b). Preparation and properties of a protein ( $R$ antigen) occurring in streptococci of group $A$, type 28 and in certain streptococci of other serological groups. J. exp. Med. 96, 83.

Maxted, W. R. (1953). The $M$ and $T$ antigens of Streptococcus pyogenes type 2. J. Path Bact. 65, 345. 


\section{Precipitating antigen of S. pyogenes type 4}

Maxted, W. R. (1956). The indirect bactericida? test as a means of identifying antibody to the M antigen of Streptococcus pyogenes. Brit. J. exp. Path. 37, 415.

Pakula, R. (1951). The extraction of the T antigen of Streptococcus pyogenes. J. gen. Microbiol. 5, 640.

Stewart, W. A., Lancefield, R. C., Wilson, A. T. \& Swift, H. F. (1944). Studies on the antigenic composition of group $\mathbf{A}$ hemolytic streptococci. IV. Related $\mathbf{T}$ but distinct $M$ antigens in types $15,17,19,23,30$ and in types $4,24,26,28,29$, 46. Identification by slide agglutination. J. exp. Med. 79, 99.

Swift, H. F., Wilson, A. T. \& Lancefield, R. C. (1943). Typing group A hemolytic streptococci by $\mathrm{M}$ precipitin reactions in capillary pipettes. J. exp. Med. 78, 127.

Wiley, G. G. \& Wilson, A. T. (1956). The ability of group A streptococci killed by heat or mercury arc irradiation to resist ingestion by phagocytes. $J$. exp. Med. $103,15$.

Wormald, P. J. (1956). Some observations on the influence of the micro-environment on loss of M substance in strains of Streptococcus pyogenes. J. Hyg., Camb. 54, 89. 